\title{
The Assessment of Tribiological Properties and the Condition of the Surface of Tool Steel for Hot Work 55nicrmov6 Subjected to the Process of Friction
}

\author{
Krzysztof Dziedzic ${ }^{1}$, Jerzy Józwik ${ }^{2}$, Marcin Barszcz ${ }^{1}$ \\ ${ }^{1}$ Fundamentals of Technology Faculty, Lublin University of Technology, 38 Nadbystrzycka Street, 20-618 Lublin, Po- \\ land, e-mail:k.dziedzic@pollub.pl,m.barszcz@pollub.pl \\ ${ }^{2}$ Department of Production Engineering, Mechanical Engineering Faculty, Lublin University of Technology, \\ 36 Nadbystrzycka Street, 20-816 Lublin, Poland, e-mail: j.jozwik@pollub.pl
}

The paper presents the evaluation of tribiological properties and condition of the tool steel surface for hot work $55 \mathrm{NiCrMoV6}$ (WNL). Due to the fact that the steel $55 \mathrm{NiCrMoV6}$ is used for components operating at high temperature, the tribological tests were performed at the room temperature as well as higher temperature $\left(150{ }^{\circ} \mathrm{C}\right)$. The wear tests were performer with help of ball-on-disc tribotester, according to the standard ASTM G-99. The applied load was $5 \mathrm{~N}$ and $20 \mathrm{~N}$. The counter specimen consisted of balls with the diameter of $6 \mathrm{~mm}$ made of steel 100Cr6. Steel samples 55NiCrMoV6 undergone thermal improvement. The average hardness amounted to 57 HRC. The test was performed with the slip speed of the friction pair $0.15 \mathrm{~m} / \mathrm{s}$ and sliding distance $200 \mathrm{~m}$. During the test, one registered the friction coefficient, frictional force, temperature and the depth of friction. Then, one calculated the wear rate for the friction agents. The evaluation of friction was performed after tribiological tests. For the load of $5 \mathrm{~N}$ the average friction coefficient in the room temperature amounted to $\mu=0.46$. At the temperature of $150{ }^{\circ} \mathrm{C}$ it increased up to $\mu=0.69$. The wear rate for the sample subjected to tests at room temperature was $3.618 \times 10^{-5} \mathrm{~mm}^{3} \mathrm{~N}^{-1} \mathrm{~m}^{-1}$. At the temperature of $150{ }^{\circ} \mathrm{C}$ it increased up to $8.058 \times 10^{-5} \mathrm{~mm}^{3} \mathrm{~N}^{-1} \mathrm{~m}^{-1}$. The maximum Herzian stress was 1.099 GPa.

For the load of $20 \mathrm{~N}$ an average friction coefficient at the room temperature was $\mu=0.69$. At the temperature of $150{ }^{\circ} \mathrm{C}$ the friction coefficient was $\boldsymbol{\mu}=0.57$. The wear rate for the sample subjected to tests at the room temperature amounted to $2.136 \times 10^{-5} \mathrm{~mm}^{3} \mathrm{~N}^{-1} \mathrm{~m}^{-1}$. At the temperature of $150{ }^{\circ} \mathrm{C}$ it increased up to $2.737 \times 10^{-5} \mathrm{~mm}^{3} \mathrm{~N}^{-1} \mathrm{~m}^{-1}$. The maximum Herzian stress was $1.741 \mathrm{GPa}$. The wear of the steel $55 \mathrm{NiCrMoV6}$ increased with the increased temperature. It has been confirmed by application of two different loads. The basic wear consisted in abrasive wear.

Keywords: tribological properties, friction, tool steel for hot work 55NiCrMoV6, condition of the surface

\section{References}

[1] HAWRYLUK, M., ZWIERZCHOWSKI, M. (2009). Structural analysis of hot forming dies with regard to their life. In: Maintenance and reliability, No. 2, pp. $31-41$.

[2] GRONOSTAJSKI, Z., HAWRYLUK, M., KUZIAK, R., RADWANSKI, K., SKUBISZEWSKI, T., ZWIERZCHOWSKI, M. (2012). The equal channel angular extrusion process of multiphase high strength aluminium bronze. In: Archives of Metallurgy and Materials, No. 4, pp. 897 - 909.

[3] GRONOSTAJSKI, Z., HAWRYLUK, M. (2008). The main aspects of precision forging. In: Archives of civil and mechanical engineering, No. 8(2), pp. $39-57$.

[4] MÜLLER, M., VALASEK, P. (2012). Abrasive wear effect on Polyethylene, Polyamide 6 and polymeric particle composites. In: Manufacturing technology, Vol. 12, No. 12, pp. 55 - 59.

[5] NAPRSTKOVA, N., SVOBODOVA, J., CAIS, J. (2013). Influence of strontium in AlSi7Mg0.3 alloy on the tool wear. In: Manufacturing Technology, Vol. 13, No. 3, pp. 368 - 373.

[6] LIN, J., MISHRA, B., MOORE, J., SPROUL, W. (2008). A study of the oxidation behavior of CrN and CrAlN thin films in air using DSC and TGA analyses. In: Surf. Coat. Technol., No. 202, pp. 3272 - 3283.

[7] SINGH, K., LIMAYE, P., SONI, N., GROVER, A., AGRAWAL, R., SURI, A. (2005). Wear studies of (Ti-Al) $\mathrm{N}$ coatings deposited by reactive magnetron sputtering. In: Wear, No. 258, pp. $1813-1824$.

[8] PANJAN, P., CVAHTE, P., CEKADA, M., NAVINSEK, B., URANKAR, I. (2001). PVD CrN coating for protection of extrusion dies. In: Vacuum, No. 61, pp. $241-244$.

[9] NAPRSTKOVA, N., CAIS, J., STANCEKOVA, D. (2014). Influence of AlSi7Mg0.3 alloy modification by Sb on the tool wear. In: Manufacturing technology, Vol. 14, No. 1, pp. $75-79$.

[10]JERINA, J., KALIN, M. (2014). Initiation and evolution of the aluminium alloy transfer on hot work tool steel at temperatures from $20{ }^{\circ} \mathrm{C}$ to $500{ }^{\circ} \mathrm{C}$. In: Wear, No. 319 , pp. $234-244$. 
[11]NAPRSTKOVA, N., CERVINKA, R., KUSMIERCZAK, S., CAIS, J. (2015). Modifications AlSi9CuMnNi alloy by ntimony and heat treatment and their influence on the resulting structure. In: Manufacturing technology, Vol. 15, No. 4, pp. $634-638$.

[12]PELLIZZARI, M. (2011). High temperature wear and friction behaviour of nitrided, PVD-duplex and CVD coated tool steel against $6082 \mathrm{Al}$ alloy. In: Wear, No. 271, pp. 2089 - 2099.

[13]KALIN, M., JERINA, J. (2015). The effect of temperature and sliding distance on coated (CrN, TiAlN) and uncoated nitrided hot-work tool steels against an aluminium alloy. In: Wear, No. 330-331, pp. $371-379$.

[14]AL-BUKHAITI, M.A., AL-HATAB, K.A., TILLMANN, W., HOFFMANN, F., SPRUTE, T. (2014). Tribological and mechanical properties of Ti/TiAlN/TiAlCN nanoscale multilayer PVD coatings deposited on AISI H11 hot work tool steel. In: Applied surface science, No. 318, pp. 180 - 190.

[15]DOBRZAŃSKI, L.A., PIEC, M., KLIMPEL, A. (2007). Improvement of the hot work tool steel surface layers properties using a high power diode laser. In: Journal of achievements in materials and manufacturing engineering, No. 21, pp. $13-22$.

[16]DOBRZAŃSKI, L.A., JONDA, E., LABISZ, K., BONEK, M., KLIMPEL, A. (2010). The comparision of tribological properties of the surface layer of the hot work tool steels obtained by laser alloying. In: Journal of achievements in materials and manufacturing engineering, No. 42, pp. $142-147$.

[17] YILBAS, B.S., PATEL, F., KARATAS, C. (2015). Laser controlled melting of H12 hot-work tool steel with B4C particles at the surface. In: Optics and laser technology, No. 74, pp. $36-42$.

[18]LUKOVICS, I., MALACHOVA, M. (2012). Laser machining of chosen materials. In: Manufacturing technology, Vol. 12, No. 12, pp. $38-42$.

[19]LEE, J., JANG, J., JOO, B., SON, Y., MOON, Y. (2009). Laser surface hardening of AISI H13 tool steel. In: Transactions of nonferrous metals society of China, No. 19, pp. 917 - 920. 